\title{
Urgences
}

\section{Enfance. L'éternelle conséquence}

\section{Denise Desautels}

Numéro 15, octobre 1986

Épigraphiques

URI : https://id.erudit.org/iderudit/025278ar

DOI : https://doi.org/10.7202/025278ar

Aller au sommaire du numéro

Éditeur(s)

Urgences

ISSN

0226-9554 (imprimé)

1927-3924 (numérique)

Découvrir la revue

Citer ce document

Desautels, D. (1986). Enfance. L'éternelle conséquence. Urgences, (15), 9-9.

https://doi.org/10.7202/025278ar d'utilisation que vous pouvez consulter en ligne.

https://apropos.erudit.org/fr/usagers/politique-dutilisation/ 


\section{Denise Desautels ENFANCE. L'ÉTERNELLE CONSÉQUENCE}

Car ce n'est pas l'irréversible que je découvre en elle, c'est l'irréductible: tout ce qui est encore en moi, par accès.

Roland Barthes par Roland Barthes

Miroir. Une réflexion infinie d'ombre.

Des gestes. Des parcours circulaires. Des adhérences.

Le mot: triste.

On pourrait superposer les regards, les gestes, les objets.

Confondre les visages et les couleurs.

Nécessairement l'ombre et l'eau.

Le mot.

Je ne recule devant rien. Ni le doute. Le soupçon.

L'artifice et la contagion.

Sans résistance, le mot. Ses reflets. Sa blessure.

Je m'essouffle à compter les désastres.

À demi-mot, je le devine: tout se perd.

Les mains inutiles.

: tout se perd.

Sinon l'empreinte inaltérable de la pierre.

Sinon la multiplication des liquides.

Les ressemblances.

L'inscription: larmes et eaux.

Le mot: triste.

Et la Mère, fermant le livre du devoir..

Rimbaud: "Les poètes de sept ans"

... j'en porte en moi les mille et un visages. 